Brian W. Martin 1,3, Ursula Ackermann-Liebrich 1,3, Philippe Leuenberger 2,3, Nino Künzli ${ }^{1,3}$, Elisabeth Zemp Stutz ${ }^{1,3}$, Roland Keller ${ }^{3}$, Jean-Pierre Zellweger ${ }^{3}$, Brunello Wüthrich ${ }^{3}$, Christian Monn ${ }^{3}$, Kurt Blaser ${ }^{3}$, Gianfranco Bolognini ${ }^{3}$, Jean-Pierre Bongard ${ }^{3}$, Otto Brändli ${ }^{3}$, Peter Braun ${ }^{3}$, Claudio Defila ${ }^{3}$, Guido Domenighetti ${ }^{3}$, Leticia Grize ${ }^{1,3}$, Werner Karrer 1,3, Harriet Keller-Wossidlo ${ }^{1}$, Tullio C. Medici ${ }^{1}$, Annie Peeters ${ }^{1}$, André P. Perruchoud ${ }^{3}$, Christian Schindler ${ }^{1,3}$, Martin H. Schoeni ${ }^{3}$, Joel Schwartz ${ }^{3}$, Gianmaria Solari ${ }^{3}$, Jean-Marie Tschopp ${ }^{3}$, Beat Villiger ${ }^{3}$ (SAPALDIA Team)

1 Institute of Social and Preventive Medicine, University of Basle

${ }^{2}$ Division of Respiratory Medicine, University Hospital of Lausanne

3 SAPALDIA Team (list of participating institutions at the end of the article)*

\section{SAPALDIA: Methods and participation in the cross-sectional part of the Swiss Study on Air Pollution and Lung Diseases in Adults}

\section{Summary}

SAPALDIA - the SWISS Study on Air Pollution and Lung Diseases in Adults - focuses on the long term health effects of low to moderate levels of air pollutants as typically seen in different parts of Switzerland. The aim of the SAPALDIA cross-sectional study carried out in 1991 was to determine the prevalence of bronchial asthma, chronic bronchitis and allergic conditions in the aduit population of Switzerland and to identify and to determine the respective importance of potentially influencing factors. These could be both personal (smoking habits, allergy status, family history, occupation) and environmental (outdoor and indoor pollution, aeroallergens, climate). A further aim of the cross-sectional study consisted in the identification of individuals susceptible to present symptoms during a two year observation period and to be included in the SAPALDIA follow-up study. This technical report reoresents the methodological documentation for the cross-sectional study of SAPALDIA. The instruments and the methods of standardisation are presented and discussed. The medical examination consisted of a computerised interview using a standardised questionnaire, the taking of a blood sample for serological tests, allergy skin testing, the measurement of endexpiratory $\mathrm{CO}$ and body height and pulmonary function testing followed by methacholine challenge testing or bronchodilatation testing. The pattern of participation and the 9651 participants of the study, representing $59.3 \%$ of the sample, are described. Based on information on non-participants gained by telephone interviews and malled short questionnaires, possible selection biases are quantified and discussed.
Chronic obstructive lung diseases contribute to morbidity and mortality in western countries including Switzerland in an important way and represent a major public health issue $^{1-3}$. As awareness of environmental problems in general has grown, the role of air pollutants as a potential cause of respiratory problems has become an important issue in the public debate ${ }^{4,5}$. Though the short and intermediate term effects of air pollutants are well established through extensive investigations $^{6-9}$, knowledge of population based prevalences of chronic obstructive lung diseases and bronchial asthma in particular is limited ${ }^{10}$. In addition, little is known about the relationship of chronic lung disease with low to moderate levels of long term air pollution, particularly in Europe or Switzerland ${ }^{\mathfrak{l n}, 12}$.

\footnotetext{
* SAPALDIA is part of the Swiss National Research Programme 26A supported by the Swiss National Foundation (Grant No 4026-28099) and by the Federal Office of Education and Science. SAPALDIA Basle is part of the European Respiratory Health Survey.
} 
The European Community Respiratory Health Survey aims at estimating the prevalence of asthma, asthma-like symptoms, and bronchial reactivity and at assessing their association with known or suspected risk factors ${ }^{13}$. Though this study has made a major effort in standardising methods of measuring the prevalence of asthma, it was beyond the scope of the project to do the same for the methods of measuring air pollution.

SAPALDIA, the Swiss Study on Air Pollution and Lung Diseases in Adults, focused on the long term health effects of low to moderate levels of air pollutants as typically seen in the different parts of Switzerland. Being part of the European Commmunity Respiratory Health Survey, the study used the same standardisation methods for the health assessment techniques. SAPALDIA consisted of two parts, a cross-sectional study conducted in 1991 and a follow-up study during the two following years. This publication presents the methods used in the cross-sectional study.

The main aim of the SAPALDIA cross-sectional study was to determine the prevalence of bronchial asthma, chronic bronchitis and allergic conditions in the adult population of Switzerland and to identify and to determine the respective importance of potentially influencing factors, both on the personal (smoking habits, allergy status, family history, occupation) and environmental level (outdoor and indoor pollution, aeroallergens, climate).

The main hypothesis was that, after taking into account the known risk factors, there exists a relationship between the level of air pollutants in the range observed in the different parts of Switzerland and the health parameters under observation. Due to the information available, it was also possible to test further hypotheses regarding the other factors under observation, for example concerning the effects of passive smoking on health ${ }^{14}$. A further aim of the cross-sectional study consisted in the identification of individuals susceptible to present symptoms during a prolonged observation period - so they could be included in the SAPALDIA follow-up study. This subsequent study - running over a period of two years - aimed at studying the relationship between environmental conditions and respiratory symptoms in susceptible persons with asthma, chronic bronchitis or elevated bronchial reactivity and in control subjects selected from the cross-sectional study.

This technical report represents the base documentation for the crosssectional study of SAPALDIA.

\section{Methods}

The sample

\section{Selection of areas}

The eight areas participating in the SAPALDIA project (Table 1) were chosen to represent the variety of environmental conditions found in Switzerland concerning geography, climate, degree of urbanisation and air pollution. In detail, the selection criteria were:

- Level of air pollution: $\mathrm{SO}_{2}, \mathrm{NO}_{2}$, Ozone, TSP.

- Meteorological characteristics: duration of sunshine, precipitation, humidity, temperature, fog counts.

- Degree of urbanisation/geography: urban, suburban, rural, high altitude/alpine (more than 1500 metres above see level).

Table 1 summarises these conditions: Compared to the other centres, the three urban areas are showing high mean levels of air pollution, one of them in a sunny climate south of the Alps (Lugano), the two other ones in more pronounced foggy and cloudy weather conditions (Basle, Geneva). Aarau represents a urban-suburban centre with variable levels of air pollution and a rather foggy climate, Payerne and Wald are two rural areas with lower air pollution and varying weather conditions. Davos and Montana are two alpine regions with low air pollution levels.

\section{Selection of subjects}

The SAPALDIA study population was based on random population samples from the local registries of inhabitants. To meet the selection criteria, individuals had to be 18 to 60 years of age by December 1990 , local residents for at least three years, Swiss nationals or foreigners with a residence permit. Because of language problems, all Turkish citizens (in $19911.03 \%$ of the Swiss population ${ }^{15}$ ) were excluded from the sample frame.

In each area separate samples were drawn using a random number programme, except for Payerne, where the subjects were randomly drawn by hand, and for a part of the Montana sample, where some of the foreign residents were not recorded in the electronic registry system and had to be randomly selected by hand as well. Table 2 shows the total population size of the different centres, sometimes consisting of several political communities, the respective sample frames and samples.

\section{Health assessment}

\section{Local SAPALDLA research centres}

For each of the research centres a local respiratory physician was responsible for the local team. The fieldworker team consisted of a junior physician and one or more paramedical assistants. All methods applied were strictly standardised and the teams were exten- 


\begin{tabular}{|c|c|c|c|c|c|c|c|c|}
\hline Centre & & $\begin{array}{l}\text { Temperature } \\
\left({ }^{\circ} \mathrm{C}\right) \\
\text { annual } \\
\text { mean }\end{array}$ & $\begin{array}{l}\text { Sunshine } \\
\text { duration } \\
\text { (h/y) }\end{array}$ & $\begin{array}{l}\text { Precipitation } \\
(\mathrm{mm} / \mathrm{y})\end{array}$ & $\begin{array}{l}\mathrm{SO}_{2} \\
\left(\mu \mathrm{g} / \mathrm{m}^{3}\right) \\
\text { annual } \\
\text { mean }\end{array}$ & $\begin{array}{l}\mathrm{NO}_{2} \\
\left(\mu \mathrm{g} / \mathrm{m}^{3}\right) \\
\text { annual } \\
\text { mean }\end{array}$ & $\begin{array}{l}\mathrm{TSP} \\
\left(\mu \mathrm{g} / \mathrm{m}^{3}\right) \\
\text { annual } \\
\text { mean }\end{array}$ & $\begin{array}{l}O_{3} \\
\left(\mu \mathrm{g} / \mathrm{m}^{3}\right) \\
98 \% \\
\text { value }\end{array}$ \\
\hline Geneva & $391 \mathrm{~m}$ & 10.4 & 1853 & 744 & 17 & 58 & 53 & 231 \\
\hline Basle & $277 \mathrm{~m}$ & 10.0 & 1784 & 758 & 14 & 51 & 45 & 131 \\
\hline Lugano. & $335 \mathrm{~m}$ & 12.3 & 2077 & 1287 & 26 & 51 & 49 & 244 \\
\hline Aarau & $384 \mathrm{~m}$ & 9.0 & 1507 & 860 & 12 & 43 & 49 & 153 \\
\hline Wald & $616 \mathrm{~m}$ & 9.7 & $1715^{\circ}$ & -6 & 7 & 22 & 35 & 163 \\
\hline Payerne & $452 \mathrm{~m}$ & 9.0 & 1796 & 780 & 4 & 23 & 34 & 162 \\
\hline Davos & $1560 \mathrm{~m}$ & 3.2 & 1803 & 914 & 8 & 21 & 15 & 129 \\
\hline Montana & $1531 \mathrm{~m}$ & 5.7 & 2305 & 881 & $<4$ & 10 & 10 & 154 \\
\hline
\end{tabular}

Table 1. Climate and air pollution characteristics of the eight SAPALDIA centres in 1991. Sunshine duration and precipitation values are annual sums, Temperature, $\mathrm{SO}_{2}, \mathrm{NO}_{2}$, and TSP (total suspended particles) annual means. Ozone is described as the 98 th percentile of all measurements $(1 / 2$ hour time resolution) of the month with the highest values in the year. For each centre the altitude of the main train or bus station is indicated in metres above sea level.

\begin{tabular}{lccc} 
Centre & $\begin{array}{c}\text { Total } \\
\text { population }\end{array}$ & $\begin{array}{c}\text { Sample } \\
\text { frame }\end{array}$ & Sample \\
\hline Geneva & 167000 & 84913 & 2549 \\
Basle & 196000 & 94120 & 2499 \\
Lugano & 26000 & 11439 & 2494 \\
Aarau & 24000 & 10522 & 2502 \\
Wald & 13500 & 4572 & 2494 \\
Payerne & 6900 & 3239 & 2300 \\
Davos (alpine region) & 10000 & 3816 & 1249 \\
Montana (alpine region) & 11200 & 4653 & 1224 \\
& & & \\
Total & 454600 & 217274 & 17311 \\
\hline
\end{tabular}

Table 2. Total population, sample frames and sample sizes of the eight SAPALDIA centres.

sively trained before the beginning of the data collection period.

The individuals in the study sample were contacted in random order throughout 1991 and invited to the research centre by the local team. Contact was made by mail and if necessary also by telephone or through personal visits. During their visit at the centre, the participants were first interviewed by a fieldworker using a standardised questionnaire, then a blood sample was taken, an allergy skin test was performed and endexpiratory $\mathrm{CO}$ and body height were measured before the pulmonary function testing took place.
Individuals unwilling to participate were asked a number of basic questions on sex, age, general health and smoking habits by telephone. All non-participants also received the mailed short questionnaire of the European Community Respiratory Health Survey ${ }^{13}$ covering sex, age, respiratory health and smoking habits.

As the Basle local research centre also took part in the European Community Respiratory Health Survey, an additional random population sample of 5000 inidividuals (local residents for at least 3 years, age of 20-44 years) was drawn. They all were sent the European short questionnaire, and out of the individuals reporting symptoms 202 participants were randomly selected and given the full SAPALDIA testing plus specific IgE serum tests. All the local SAPALDIA participants meeting the European age criteria ( 854 subjects) were also asked to complete the European short questionnaire and specific $\operatorname{IgE}$ were determined in them as well ${ }^{13}$. 


\section{Instruments}

The standardised methods for the interview, allergy testing with skin and blood tests, lung function and bronchial challenge testing were developed in coordination with the European Community Respiratory Health Survey ${ }^{13}$. The fieldworkers of the local research teams were given detailed instructions in several centralised workshops and had an intense two month pilot period practising the health assessment techniques under supervision before the onset of the study.

All relevant information concerning methods and organisation of the study was described in form of written instructions distributed to all local research teams and the local responsible respiratory physicians. During the study the research teams were under supervision by the local respiratory physician and the central epidemiology unit of the study. Apart from individual contacts four plenary meetings were held in 1991 to exchange experiences and to improve and maintain the methodological standards.

\section{SALPADIA questionnaire}

The computerised SAPALDIA questionnaire of the cross-sectional study was developed along with the questionnaire of the European Community Respiratory Health Survey ${ }^{13}$. It dealt with the personal history of respiratory symptoms, family history, occupation, living conditions, exposure to animals, smoking and general health. In comparison to the European questionnaire, the SAPALDIA sections concerning exposure to tobacco smoke, indoor environment and occupational exposure were more extensive. As the aim of the study was not compatible with urine collection to validate the respective questions, the dietary questions of the European questionnaire were not included. Table 3 shows the different sections of the
SAPALDIA questionnaire compared to the European questionnaire. According to the local languages in the different centres, three different versions of the questionnaire in German, French and Italian were used. In order to prevent bias due to translation errors and to minimise bias due to linguistic differences, a process of translation and cross-translation was applied. First a German questionnaire was created, using questions translated from the English original of the European questionnaire. Additional questions were created, the socioeconomic questions were taken from the Swiss national census, the questions on smoking and passive smoking were adopted from the MONICA questionnaires. The questions in the French and Italian versions were translated from the German ones, unless they already existed in the respective languages in the first place. The French and Italian questionnaires were subsequently translated into German by an independent translator, and the three German versions were compared by a team. In a final step, all three versions were translated back into English and inconsistencies between the original and the retranslated questions were explored and removed.

\section{End-expiratory $\mathrm{CO}$}

End-expiratory $\mathrm{CO}$ was measured with a EC50 Micro-Smokerlizer Bedfont. Participants were asked to first completely exhale, then completely inhale, hold their breath for at least 20 seconds and finally exhale completely through the mouthpiece of the measuring device. As alveolar partial pressure of $\mathrm{CO}$ is correlated to blood levels of carboxyhaemoglobin, this was a measure of validating the participants' answers to smoking habits.

\section{Pulmonary function testing}

In pulmonary function testing forced expiratory manoeuvres were performed in order to record the forced expiratory volume in one second (FEV1), the forced vital capacity (FVC) and different expiratory flow values. The instrument used was a Pulmonary Function System SensorMedics $2200 \mathrm{SP}$ using a mass flow anemometer, displaying and recording flow-volume curves for each trial. The testing was performed by a trained fieldworker according to the recommendations on standardisation of spirometry of the American Thoracic Society ATS $^{16}$. Three ATS acceptability criteria (volume of

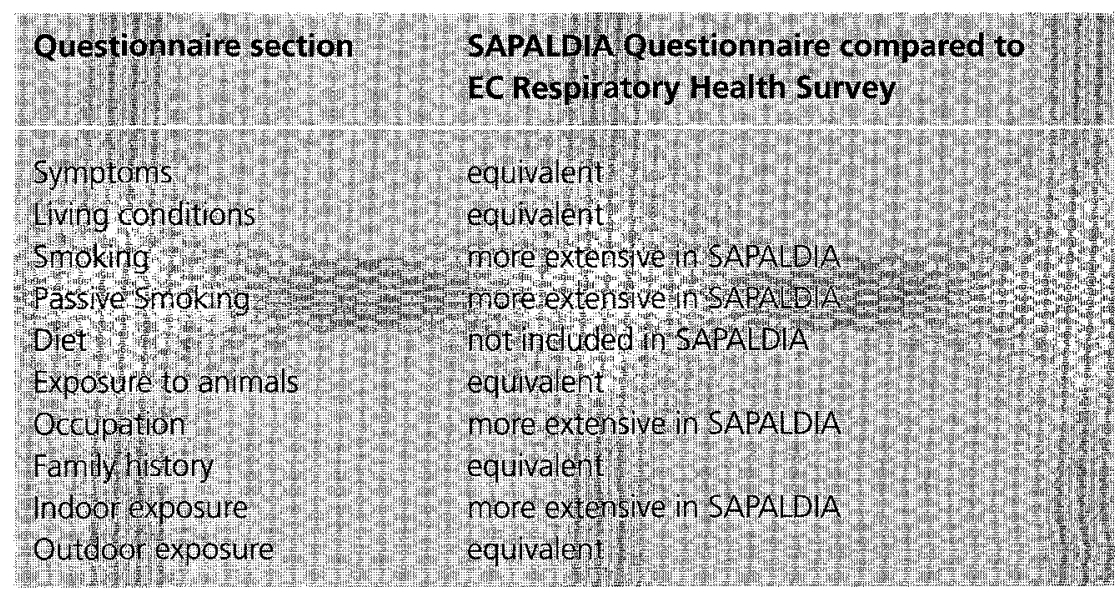

Table 3. Structure of the questionnaires of SAPALDIA and the European Community Respiratory Health Survey in comparison. 
extrapolation less than $5 \%$ FVC or less than $100 \mathrm{ml}$, expiratory time of at least 6 seconds, end of test: no volume change for the last 2 seconds of the manoeuvre) were displayed and recorded with each manoeuvre. The two ATS reproducibility criteria (largest two FVC and FEV1 values within $5 \%$ of one another) were recorded with the set of best values and guided the technicians decisions for additional manoeuvres. At least three and up to eight manoeuvres were required, until the 5 criteria described were met.

Each day before spirometry testing the spirometer was calibrated with a three litre syringe. Tests were performed to assess between-centre and within-centre variability as well as variability between devices and showed satisfactory results ${ }^{17}$.

All spirometry outputs were visually screened by a junior physician with experience in lung function testing and a qualified respiratory physician. 192 flow-volume curves in 116 individuals were suggestive of coughing or glottis closure and were excluded. The spirometry technicians also had the option of commenting manouvres and their critical remarks caused another 40 exclusions.

For the analysis of spirometry data, the best volume values (FVC, FEV1) were chosen from the three best manoeuvres recorded for each participant. For any values to become eligible, the peak flow of the corresponding curve could not exceed $16 \mathrm{l} / \mathrm{sec}$ (higher peak flows were the result of erroneous recordings due to technical limitations of the measuring device) and the manoeuvre had to pass the screening process described above. For any FVC to become eligible, the ATS-criterion of no volume change for the last two seconds of the corresponding manoeuvre had to be met, and for any FEV1, the volume of extrapolation had to be less than $5 \%$ of $\mathrm{FVC}$ or less than $100 \mathrm{ml}$. To be eligible as a best volume value, any FVC or FEV1 had to be within either $5 \%$ or $100 \mathrm{ml}$ of the highest value of FVC or FEV1 respectively before any exclusions made.

Best flow values, values of forced expiratory time and Tiffeneau (FEV1/FVC) were taken from the best eligible curve (ranking according to the sum of FVC and FEV1). For a complete curve to be eligible, both its FVC and FEV1 had to be eligible.

\section{Inhalation tests}

In participants able to produce a technically satisfactory spirometry either bronchial challenge or bronchodilatation testing was performed, conditional on the individual's consent and the fulfilment of inclusion criteria. For safety reasons a number of exclusion criteria from both tests were defined: moyocardial infarction within the last 3 months, heart disease under treatment, epilepsy under treatment, pregnancy, lactation, treatment with any $\beta$-blockers including exedrops. In all participants non-specific bronchial reactivity was assessed by inhalation challenge with methacholine chloride (Provochlorine ${ }^{\circledR}$ ), unless they had shown bronchial obstruction during spirometry. The criteria for bronchial obstruction were a FEV1/FVC below $80 \%$ or a FEV1 below $70 \%$ of the predicted values from Quanjer et al. ${ }^{18}$.

After a baseline FEV1 manoeuvre following $\mathrm{NaCl}$ inhalation methacholine chloride was administered by a Mefar aerosol dosimeter at progressing levels up to a cumulative dose of $2 \mathrm{mg}$ (see Table 4). All devices used in the SAPALDIA study belonged to the new Mefar aerosol dosimeter model developed in 1990 , producing a constant air pressure of 1.7 bar and avoiding the problem of pressure falling over time encountered in the preceding model. The dosimeter was automatically triggered at the beginning of the inhalation and subjects were instructed to hold their breath at full inspiration for 4 seconds. One and two minutes after the end of inhalation two FEV1 manoeuvres were performed and the best of the two manoeuvres was recorded. The test was ended either once the cumulative dose of $2 \mathrm{mg}$ of methacholine chloride was reached or after FEV1 had decreased by $20 \%$ or more compared to the $\mathrm{NaCl}$ baseline.

\begin{tabular}{|c|c|c|}
\hline Level & Cumulative dose (mg. methacholine) & Level status \\
\hline 1/base & 0 & standard \\
\hline 2 & 0.016 & standard \\
\hline 3 & 0.031 & intermediate \\
\hline 4 & 0.063 & standard \\
\hline 5 & 0.125 & intermedlate \\
\hline 6 & 0.250 & standard \\
\hline 7 & 0.500 & intermediate \\
\hline 8 & 1000 & standard \\
\hline 9 & 2.000 & standard \\
\hline
\end{tabular}

Table 4. Inhalation levels during the methacholine bronchial challenge testing. If no decrease in FEV1 of 10\% or more compared to the base level ( $\mathrm{NaCl}$ inhalation) was observed, testing proceeded using the standard levels only. If a decrease between $10 \%$ and $20 \%$ occurred, intermediate levels were used as well. After a decrease of $20 \%$ or more the test was stopped. 
The methacholine chloride solution used for bronchial challenge testing was supplied for all centres by the Pharmacy of the University Hospital in Lausanne. 2 samples of the solution were sent to the centre of the European Community Health Survey in London for testing in September 1991 and March 1992 and were assessed to be at $90.1 \%$ and $111.63 \%$ of the reference preparation used by the EC Health Survey.

All nebulisers were tested monthly for variation in output, but the calibration method suggested by the European Community Health Survey proved to be inappropriate and to introduce measurement errors of more than $50 \%$. So all nebulisers were replaced and recalibrated by the manufacturer. In this process, no variance of more than $10 \%$ could be detected. Looking at the bronchial reactivity data, no hint of any differences in the tests performed before and after the replacement nor of any time trend could be found. Therefore if any effect of the changing of nebulisers existed, it would be negligible.

Study participants with bronchial obstruction (FEV1/FVC below $80 \%$ or a FEV1 below $70 \%$ of the predicted values) did not undergo bronchial challenge but bronchodilatation testing. They were given an inhalation of $200 \mu \mathrm{g}$ of salbutamol, and spirometry was repeated after 10 minutes.

\section{Skin Prick Tests}

Skin prick tests (SPT) were performed on the volar forearm using Phazet (Pharmacia ${ }^{\circledR}$ ) allergen coated steel lancets, corresponding to a prick test extract of $100000 \mathrm{BU}$ (biological units) $/ \mathrm{ml}^{19}$. The inhalant allergens tested for were chosen according to the known prevalence of specific sensitisation in Switzerland and in accordance with the EC Respiratory Health Survey Allergy Testing Protocol:
- Cat fur

- Mould (Cladosporium herbarum)

- Timothy grass pollen

- Pellitory-of-the-Wall pollen (Parietaria)

- House dust mite (Dermatophagoides pteronyssinus)

- Mould (Alternaria tenuis)

- Birch pollen

- Dog epithelia

- Histamine (positive control)

- Non-coated lancet (negative control)

Being extremely rare allergens in Switzerland, olive and ragweed were not included in the selection. Dog epithelia were chosen in addition to the genuine EC Testing Protocol because they were known to be important allergens in Switzerland.

After degreasing the skin the allergen-coated $1 \mathrm{~mm}$ point of the lancet was pressed into the skin and removed after one second. After 15 minutes the perimeter of the swelling was marked by a pen and transferred to the data collection sheet using transparent tape. The widest diameter of the wheal was measured, then the largest line within the perimeter and perpendicular to the first diameter was fitted and used as a second measure. In skin prick testing fieldworkers repeatedly had to test pairs of positive controls (histamine) according to the respective protocol of the European Community Health Survey to achieve and maintain a coefficient of variation of less than $30 \%$. Also the percentage of false negative histamine tests was checked regularly and reinstruction and practising sessions were given to fieldworkers whenever necessary.

Several analyses of the SPT data were done to compare the fieldworkers within the teams using the sum of all adjusted allergen wheal diameters and a yes/no variable for any reaction to any of the allergens except histamine. An adjusted wheal diameter was defined as the mean diameter of a wheal minus the mean diameter of the negative control in the same individual, truncating at zero and therefore allowing no negative values. In three out of the eight centres differences between technicians turned out to be sigificant with respect to both variables, in two other centres either one or the other variable showed a significant variation between fieldworkers.

\section{Serological examinations}

Blood samples were taken from the participants and serum was stored at $-20^{\circ} \mathrm{C}$ before being sent to the laboratory for testing. Total serum IgE was measured using the Pharmacia CAP FEIA system and the presence of specific serum $\operatorname{IgE}$ antibodies to a mixture of relevant inhalative allergens (pollen, house dust mites, moulds, and animal epithelia) was assessed by the Phadiatop CAP FEIA test ${ }^{19,20}$.

All serum testing for $\mathrm{IgE}$ was done in the Allergy Laboratory of the Department of Dermatology, University Hospital Zurich. Extra blood samples of two volunteers (both consistently Phadiatop positive) were distributed in 120 samples each and between August and December 1991 they were randomly sent to the laboratory with serum material from the research centres. The repeated measurements of total $\mathrm{IgE}$ were more constant for the low atopic individual (109 usable observations, $\mu=18.9 \mathrm{kU} / \mathrm{l}$, coefficient of variation $13 \%$ ) than for the highly atopic person ( 99 usable observations, $\mu=560.0 \mathrm{kU} / 1$, coefficient of varition $22 \%$ ), and for both samples values were within the precision claimed by the laboratory.

\section{Environmental Data}

\section{Data available}

Three categories of environmental data from different sources were 
used for the SAPALDIA study: Meteorological data, data on air pollutants and on pollen. The details of the environmental data assessment are described in separate publications ${ }^{21,22}$.

All SAPALDIA centres but the one in Wald were equipped with an automatic meteorological station of the monitoring network of the Swiss Meteorological Institute in Zurich measuring the following parameters:

- Air temperature

- Atmospheric pressure

- Vapour pressure

- Relative humidity

- Sunshine duration

- Global radiation

- Cloudiness

- Fog observations

- Precipitation

- Thunderstorms

- Wind direction

- Wind speed

In Wald air temperature, atmospheric pressure, vapour pressure, relative humidity, wind direction, and wind speed were recorded by the automatic air pollution monitoring station and sunshine duration was measured by a Sunshine Autograph Fuess.

For the continuous measurement of air pollutants all centres were equipped with at least one automatic monitoring station for sulphur dioxide $\left(\mathrm{SO}_{2}\right)$, nitrogen oxides
$\left(\mathrm{NO}_{\mathrm{X}}\right)$, nitrogen dioxide $\left(\mathrm{NO}_{2}\right)$, nitrogen monoxide (NO), ozone $\left(\mathrm{O}_{3}\right)$ and total suspended particles (TSP). Carbon monoxide (CO) was measured in all centres but Aarau and Payerne. The time resolution was 1 day for TSP and 1/2 hour for all other pollutants. In 1992 daily particulate matter of less than $10 \mu \mathrm{m}$ (PM10) measurements were introducted in all 8 areas. The automatic stations were run by local, cantonal or national institutions.

To gain further information on air pollution, several additional measurements were made. From July 1991 on, in three centres particulates were sampled by a low-pressure impactor to assess size-fractions of suspended particles. Geneva, Aarau and Davos were chosen to represent a city, an urban-suburban area on the Swiss plateau and an alpine region.

To obtain more information on the local distribution of air pollution concentrations, a passive sampling network for $\mathrm{SO}_{2}, \mathrm{NO}_{2}$ and Ozone was installed in all centres. The measurements took place simultaneously over a period of four weeks in a row giving weekly averages. Table 5 gives an overview of the seasons the passive sampling for the different pollutants took place in.

Passive sampling measurements for volatile organic compounds (VOC) were carried out for an exposure time of two weeks. They were measured at one place only in each centre simultaneously in spring, summer and autumn.

The term "acid aerosols" is not clearly defined and is sometimes used for sulphate in particles or sulphuric acid. As in Switzerland the concentrations of sulphuric acid are usually too low to be detected, nitric acid $\left(\mathrm{HNO}_{3}\right)$, the major compound responsible for airborne acidity in Switzerland, was measured as well as amonia $\left(\mathrm{NH}_{3}\right)$, a possible neutralising agent of nitric acid ${ }^{23}$. Measurements were carried out in all centres during the same period using a passive sampling technique over four consecutive weeks in spring, summer and autumn.

Pollen measurements were carried out from the end of February until the end of Septemer 1991, using the Burkard seven days volumetric spore trap, a method yielding results corresponding to the pollen concentration in one cubic metre of air per day. The data were analysed by aeropallynologists of the Swiss working Group for Aerobiology. The allergen pollen considered in the analyses for all centres were:

- Alder (Alnus sp.)

- Hazel (Corylus sp.)

- Birch (Betula sp.)

- Grass (Gramineae/Poaceae)

- Mugwort (Artemisia sp.)

\begin{tabular}{|c|c|c|c|c|c|c|c|c|}
\hline & Geneva & Basle & Lugano & Aarau & Wald & Payerne & Davos & Montana \\
\hline sP impactor meas. & $1 \mathrm{ul}+\mathrm{Dec}$ & & & $\mathrm{Ju}-\mathrm{Dec}$ & & & Jul-Dec & \\
\hline $\begin{array}{l}\mathrm{NO}_{2} \text { passive sampling } \\
\mathrm{SO}_{2} \text { passive sampling }\end{array}$ & $\mathrm{w} / \mathrm{sp} / \mathrm{su} / \mathrm{a}$ & $\begin{array}{l}\text { W/sp/su/a } \\
\text { w }\end{array}$ & $\begin{array}{l}\text { w/sp/su/a } \\
\text { w }\end{array}$ & $\begin{array}{l}w / s p / s u / a \\
w\end{array}$ & $\mathrm{w} / \mathrm{sp} / \mathrm{su} / \mathrm{a}$ & $\mathrm{w} / \mathrm{sp} / \mathrm{su} / \mathrm{a}$ & $\mathrm{w} / \mathrm{sp} / \mathrm{su} / \mathrm{a}$ & $\mathrm{w} / \mathrm{sp} / \mathrm{su} / \mathrm{a}$ \\
\hline $\mathrm{O}_{3}$ passive sampling & sp/su/a & $\mathrm{sp} / \mathrm{su} / \mathrm{a}$ & $\mathrm{sp} / \mathrm{su} / \mathrm{a}$ & $\mathrm{sp} / \mathrm{su} / \mathrm{a}$ & $\mathrm{sp} / \mathrm{su} / \mathrm{a}$ & $\mathrm{sp} / \mathrm{su} / \mathrm{a}$ & $\mathrm{sp} / \mathrm{su} / \mathrm{a}$ & $\mathrm{sp} / \mathrm{su} / \mathrm{a}$ \\
\hline VOC passive sampling & $\mathrm{sp} / \mathrm{su} / \mathrm{a}$ & $\mathrm{sp} / \mathrm{su} / \mathrm{a}$ & sp/sula & $\mathrm{sp} / \mathrm{su} / \mathrm{a}$ & $\mathrm{sp} / \mathrm{su} / \mathrm{a}$ & sp/su/a & $\mathrm{sp} / \mathrm{su} / \mathrm{a}$ & sp/sula \\
\hline Acid aerosols & $\mathrm{sp} / \mathrm{su} / \mathrm{a}$ & sp/su/a & sp/sula & $\mathrm{sp} / \mathrm{su} / \mathrm{a}$ & $\mathrm{sp} / \mathrm{su} / \mathrm{a}$ & $\mathrm{sp} / \mathrm{sula}$ & $\mathrm{sp} / \mathrm{su} / \mathrm{a}$ & $\mathrm{so} / \mathrm{su} / \mathrm{a}$ \\
\hline
\end{tabular}

Table 5. Additional air pollutant measurements in the different centres. Passive sampling was carried out for one measurement period in winter ( $w$ ), spring (sp), summer (su) or autumn (a) depending on the air pollutant. 
In addition, Chestnut (Castanea sp.) and Pellitory-of-the-Wall (Parietaria $\mathrm{sp}$.) were considered in Lugano only. All pollen of the Nettle family (Urticaceae) were included in Pellitory-of-the-Wall (Parietaria sp.).

\section{Quality control for continuous monitors}

As different authorities and bodies were involved in these measurements, inter-field calibration comparisons were carried out in order to assess differences in calibration standards and biases in measurements. The inter-field calibration of the monitors was carried out by an independent company (Oekoscience, Zurich) at all sites. In each region, the automated reference station was controlled for the gaseous compounds $\mathrm{NO}_{2}$, $\mathrm{NO}, \mathrm{SO}_{2}, \mathrm{CO}$, and ozone.

Before inter-calibration was carried out, the local authorities calibrated the monitors with their own calibration gas. The procedure included a check of the monitors with zero-gas, passing a mixture of $\mathrm{NO}, \mathrm{NO}_{2}$ and $\mathrm{CO}$ gas through all monitors, a sensitivity check of $\mathrm{NO}$ on the $\mathrm{SO}_{2}$ monitor, a gasphase titration of the conversion of $\mathrm{NO}_{2}$ into $\mathrm{NO}$ in the $\mathrm{NO}_{\mathrm{X}}$ monitor and a check on the ozone monitor with an independent ozone generator.

The quality control for 1991 showed that most monitors were measuring within a range of $10 \%$. Only in Geneva and Montana the ozone data were overestimated by more than $20 \%$ and by $15 \%$ respectively.

For TSP, an analysis of different field inter-comparisons between the different monitors (High-VolGravimetric, beta radiation and tapered oscillation monitor) showed that there was need for a new calibration of the oscillation monitor used in the second half of 1991 at Wald. For the others, data were within a range of $\pm 15 \%$.

\section{Analyses}

\section{Data management}

The local teams sent the data from the health assessment excluding the serum tests to the epidemiology unit of the study at the Institute of Social and Preventive Medicine in Basle. The serum samples were sent to the Allergy Laboratory of the Department of Dermatology, University Hospital Zurich. There analyses were performed and the results were sent to the epidemiology unit. The environmental data was provided by the different local facilities and collected and controlled by the Institute of Hygiene and Applied Physiology of the Swiss Federal Institute of Technology in Zurich before being transferred to the epidemiology unit.

Data were processed at the central main frame computer of the "Amt für Informatik" of the canton of Basel-Stadt using the SAS programme.

\section{Data protection and data security}

Only health data that could not be linked to the identity of individuals was sent to the epidemiology unit of the study in Basle and processed there, the names of the participants being replaced by identification numbers. There were only two places were identification numbers and names could be linked: In the local research centre under the responsibility of the respiratory physician, who would give information on the health records to the participants or their treating physicians, and with the study director at the Division of Respiratory Medicine of the University Hospital in Lausanne.

The study data on the central main frame computer is only accessible to individually authorised members of the research team using their individual passwords. The local health data of the participants (spirometry outputs, allergy test results, etc.) is stored and locked away the same way as other health records under the responsibility of the local respiratory physician.

\section{Health data results}

This article focuses on the participation in the SAPALDIA crosssectional study and on the representativity of the data available. The environmental data have been presented in separate publications $^{21,22}$.

Participation

\section{Overall participation}

From the original sample of 17311 a number of 1044 individuals had to be excluded, mostly because they had moved away $(n=868)$, in some cases because they spend most of the week outside the study area $(n=62)$, because they had died $(n=51)$, or for a variety of other reasons, e.g. being in prison $(\mathrm{n}=63)$. Participation, defined as having completed at least the SAPALDIA questionnaire, was achieved for 9651 people, representing $59.3 \%$ of the eligible sample. In addition, the mailed short questionnaire of the European Community Respiratory Health Survey was obtained from 2244 persons $(13.8 \%)$, the telephone interview with basic questions on sex, age, general health and smoking habits from another 2234 $(13.7 \%) .1859$ people refused to participate in any of the interviews, 279 could not be contacted, so no information was available on $13.1 \%$ of the sample. As table 6 shows, participation varied substantially between the different centres, from $41.9 \%$ in Geneva to $74.3 \%$ in Montana. 


\begin{tabular}{|c|c|c|c|c|c|c|c|c|c|}
\hline & Geneva & Basle & Lugano & Aarau & Wald & Payerne & Davos & Montana & All centres \\
\hline $\begin{array}{l}\text { ample size } \\
\text { after exclusions }\end{array}$ & $\begin{array}{l}2387 \\
100 \%\end{array}$ & $\begin{array}{l}2405 \\
100 \%\end{array}$ & $\begin{array}{l}2292 \\
100 \%\end{array}$ & $\begin{array}{l}2354 \\
100 \%\end{array}$ & $\begin{array}{l}2393 \\
100 \%\end{array}$ & $\begin{array}{l}2213 \\
100 \%\end{array}$ & $\begin{array}{l}1154 \\
100 \%\end{array}$ & $\begin{array}{l}1069 \\
100 \%\end{array}$ & $\begin{array}{l}16267 \\
100 \%\end{array}$ \\
\hline rticipation & $\begin{array}{l}999 \\
41.9 \%\end{array}$ & $\begin{array}{l}1491 \\
62.0 \%\end{array}$ & $\begin{array}{l}1310 \\
57.2 \%\end{array}$ & $\begin{array}{l}1299 \\
55.2 \%\end{array}$ & $\begin{array}{l}1518 \\
63.4 \%\end{array}$ & $\begin{array}{l}1495 \\
67.6 \%\end{array}$ & $\begin{array}{l}745 \\
64.6 \%\end{array}$ & 794 & $\begin{array}{l}9651 \\
59.3 \%\end{array}$ \\
\hline questionnaire & $\begin{array}{l}408 \\
17.1 \%\end{array}$ & $\begin{array}{l}393 \\
16.3 \%\end{array}$ & $\begin{array}{l}391 \\
17.1 \%\end{array}$ & $\begin{array}{l}280 \\
11.9 \%\end{array}$ & $\begin{array}{l}312 \\
13.0 \%\end{array}$ & $\begin{array}{l}235 \\
10.6 \%\end{array}$ & $\begin{array}{l}120 \\
10.4 \%\end{array}$ & $\begin{array}{l}105 \\
9.8 \%\end{array}$ & $\begin{array}{l}2244 \\
138 \%\end{array}$ \\
\hline $\begin{array}{l}\text { elephone } \\
\text { interview }\end{array}$ & $\begin{array}{l}515 \\
21.6 \%\end{array}$ & $\begin{array}{l}275 \\
11.4 \%\end{array}$ & $\begin{array}{l}363 \\
15.8 \%\end{array}$ & $\begin{array}{l}374 \\
15.9 \%\end{array}$ & $\begin{array}{l}180 \\
7.5 \%\end{array}$ & $\begin{array}{l}301 \\
13.6 \%\end{array}$ & $\begin{array}{l}165 \\
14.3 \%\end{array}$ & $\begin{array}{l}61 \\
5.7 \%\end{array}$ & $\begin{array}{l}2234 \\
137 \%\end{array}$ \\
\hline informotio & $\begin{array}{l}465 \\
19.5 \%\end{array}$ & $\begin{array}{l}246 \\
10.2 \%\end{array}$ & $\begin{array}{l}228 \\
9.9 \%\end{array}$ & $\begin{array}{l}401 \\
17.0 \%\end{array}$ & $\begin{array}{l}383 \\
16.0 \%\end{array}$ & $\begin{array}{l}182 \\
8.2 \%\end{array}$ & $\begin{array}{l}124 \\
10.7 \%\end{array}$ & $\begin{array}{l}109 \\
10.2 \%\end{array}$ & $\begin{array}{l}2138 \\
13.1 \%\end{array}$ \\
\hline
\end{tabular}

Table 6. Overall participation in the study centres of the SAPALDIA cross-sectional study. Participation: at least SAPALDIA questionnaire completed. EC questionnaire: mailed short questionnaire of the European Community Repiratory Health Survey completed. Telephone interview: basic questions answered during telephone contact. No information: any interview refused or person not reached.

\section{Participation by test}

All 9651 participants of the study completed the computerised questionnaire. For the other instruments participation varied depending on the sort of examination (Table 7), being generally good for endexpiratory CO (99.2\%), spirometry $(99.0 \%)$, and skin prick testing $(97.1 \%)$. Numbers were lower for the serological tests requiring the taking of a blood sample $(89.4 \%)$ and for bronchial challenge testing $(79.0 \%)$. To interpret the small proportion of participants having undergone bronchial challenge testing and bronchodilatation testing, one has to bear in mind that only individuals with a spirometry were eligible for either of the tests, according to the results, and that only the small number of participants with bronchial obstruction was supposed to undergo bronchodilatation testing. Out of the 9552 inidividuals with a complete spirometry, 445 showed bronchial obstruction (FEV1/FVC below $80 \%$ or FEV1 below $70 \%$ of the predicted values) and therefore did not qualify for bronchial challenge testing. Out of the remaining
9107 participants, 7624 underwent bronchial challenge testing, resulting in 7384 acceptable tests (representing $81.1 \%$ of the eligible individuals). The reasons for not having any test results were: exclusion criteria in the interview (myocardial infarction within the last 3 months, heart disease under treatment, epilepsy under treatment, pregnancy, lactation, treatment with any $\beta$-blockers including eyedrops): $707(7.8 \%)$; consent for testing not given: 445 (4.9\%); other reasons (doubts about health status of the participant, unsatisfactory manoeuvres, technical problems, loss of data): $833(9.1 \%)$. More than one reason could be given.

\section{Completeness of tests}

Looking at the completeness of tests in individuals, it could be seen that $3 / 4$ of the participants had the full set of investigations consisting of the questionnaire, CO-test, serological tests, skin prick tests and spirometry with bronchial challenge or bronchodilatation testing (see Table 8 ). $81.9 \%$ of all participants had complete pulmonary test results with spirometry and bron- chial challenge or bronchodilatation testing. $95.3 \%$ had complete information concerning atopy or hyperreactivity with results from bronchochallenge testing, serological tests or both.

The completeness of tests was better in males $(79.4 \%$ versus $71.4 \%$ in females). The difference became smaller when looking at participants with complete pulmonary test results $(85.0 \%$ vs. $79.0 \%)$ or complete information concerning atopy or hyperreactivity $(96.2 \%$ vs. $94.4 \%)$.

Description of participants and representativity

Age

The age distribution for all participants was $19.8 \%$ under 30 years of age, $38.3 \%$ between 30 and 44 years and $41.9 \%$ with more than 44 years. In the different centres these proportions were similar, varying from $11.3 \%$ to $22.5 \%$ for the youngest age group, $33.4 \%$ to $47.8 \%$ for the intermediate one and $38.3 \%$ to $47.9 \%$ for the oldest one.

Comparing the age structure in the SAPALDIA participants with the 


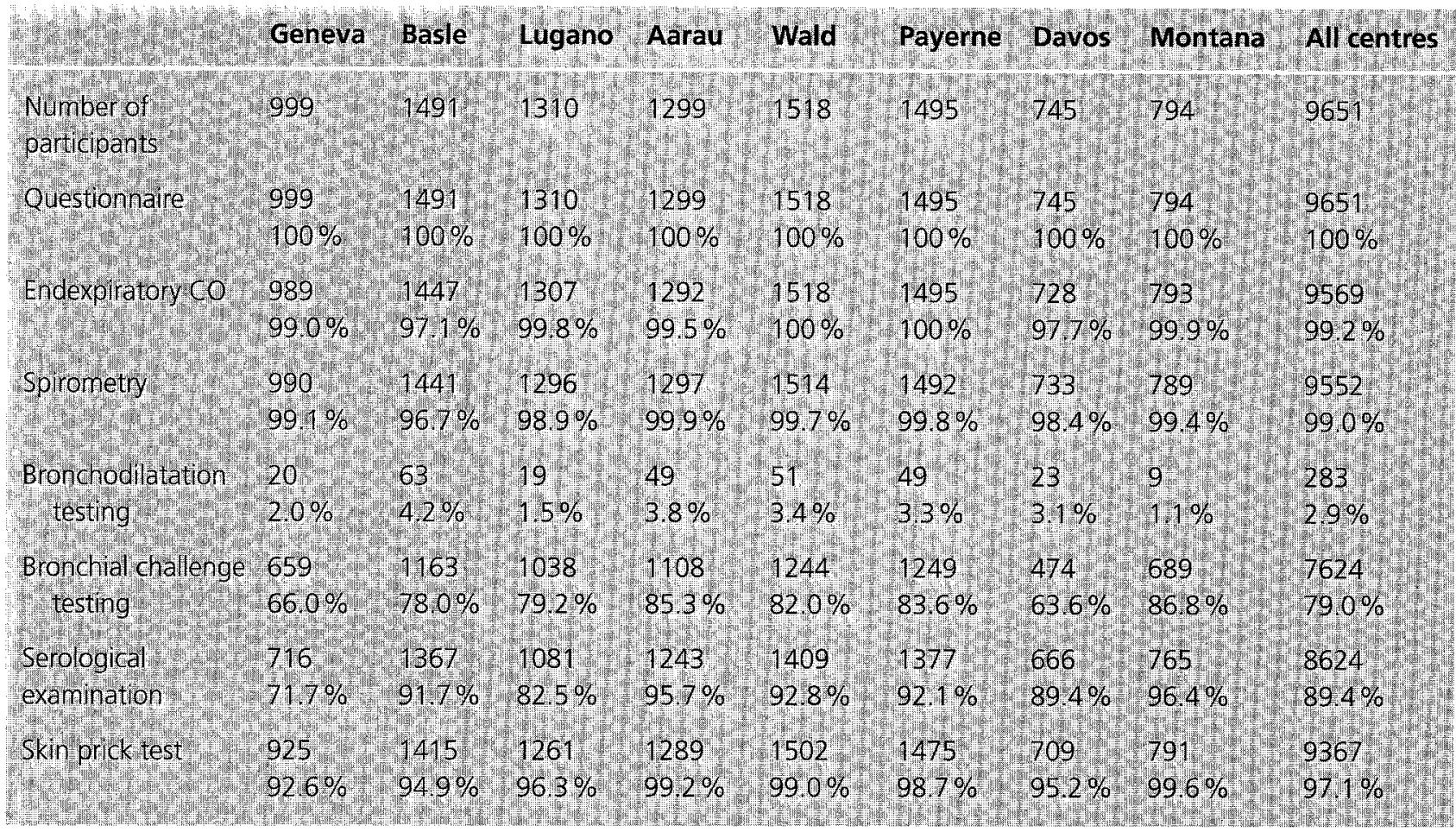

Table 7. Participation in the different tests of the SAPALDIA cross-sectional study. By definition all participants had answered the questionnaire. Only individuals with a spirometry were eligible for either bronchodilatation or bronchial challenge testing, according to the results of the test. Only the small proportion of participants with bronchial obstruction was eligible for bronchodilatation testing.

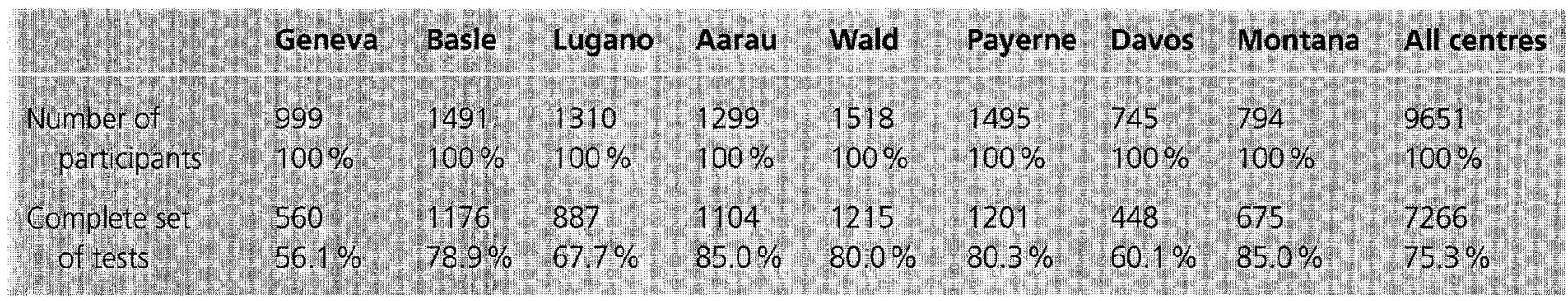

Table 8. Completeness of tests in the different centres. A complete set of tests consisted of the questionnaire, CO-test, serological tests, skin prick tests and spirometry with bronchial challenge or bronchodilatation testing. 7907 individuals (81.9\% of all participants) had complete pulmonary test results with spirometry and bronchial challenge or bronchodilatation testing. 9197 individuals (95.3\%) had complete information concerning atopy or hyperreactivity with results from bronchochallenge testing, serological tests or both.

one in the population of the different centres by the end of 1991, a clear overrepresentation of the oldest age group (more than 44 years of age) and a clear underrepresentation of the youngest age group (less than 30 years of age) could be seen in all centres. This comparison might be misleading as it was not possible to obtain information on age, sex and nationality of all the members of the original sample frame meeting the inclusion criteria. So the population consisted of all residents of the study centre areas in the respective age groups by the end of December 1991 without any restriction concerning the duration of their residency. The fact that for $70.3 \%$ (4652) of the 6616 non-participants of the SAPALDIA study information on age was available from telephone interviews or short 
questionnaires made it possible to compare their age structure with the one found in the SAPALDIA participants. The intermediate age group ( 30 to 44 years of age) was significantly overrepresented in the participants $(38.3 \%$ of the participants versus $33.3 \%$ of the nonparticipants, $\mathrm{p}<0.001$ derived from $\chi^{2}$ test), while the youngest age group $(19.8 \%$ versus $22.0 \%)$ and the oldest one were underrepresented $(41.9 \%$ vs. $44.7 \%)$. This pattern varied only little across centres.

Sex

The SALPADIA participants consisted of $50.9 \%$ females and $49.1 \%$ males. This proportion varied only little across centres, with the highest differences found in Lugano with $55.5 \%$ female participants. Also considering the sex distribution in the different age groups, there was only limited variation. The proportion of females was $47.4 \%$ in the youngest age group, $52.9 \%$ in the intermediate one, and $50.7 \%$ in the oldest one. This finding is corresponding to a significantly larger intermediate age group in the female participants $39.9 \%$ versus $36.8 \%$ of all male participants in the same age group, $\mathrm{p}<0.001$ derived from $\chi^{2}$ test), a smaller youngest age group $(18.5 \%$ vs. $21.2 \%)$ and a practically identical oldest one $(41.7 \%$ vs. $42.0 \%$ ).

Comparing the proportion of women in the participants to the proportion in the population of the study centre areas (in the respective age groups by the end of December 1991 disregarding the SAPALDIA inclusion criteria) and in the non-participants, no significant difference was found $(50.9 \%$ in the participants, $51.0 \%$ in the population, $51.1 \%$ in non-participants, information available for $99.3 \%$ of non-participants. $\mathrm{p}=0.81$ from $\chi^{2}$ test comparing participants and population, $\mathrm{p}=0.72$ compar- ing participants and non-participants). The same picture was seen in all centres with differences of less than $3 \%$ between the three different groups. Only for Basle it was possible to obtain information on the sex distribution of the local population in the respective age group who had been residents for at least three years by the end of 1991, but no significant difference could be observed here either $(50.7 \%$ females in participants versus $50.8 \%$ in the local 3 year residents, $p=0.96$ derived from $\chi^{2}$ test).

\section{Nationality}

The overall percentage of nonSwiss participants was $18.1 \%$, ranging from $33.1 \%$ in Lugano to $9.2 \%$ in Wald. This proportion was very similar in the three age groups $(16.0 \%$ in the youngest group; $18.5 \%$ in the intermediate one, $18.8 \%$ in the oldest one; $\mathrm{n}=$ 9638).

The proportion of individuals with non-Swiss nationality was significantly lower in the participants $(18.1 \%, \mathrm{n}=9638)$ than in the population of the study centre areas in the respective age groups $(32.7 \%$, $\mathrm{n}=272328, \mathrm{p}<0.001$ derived from $\chi^{2}$ test). The respective proportions varied widely between centres, but were consistently lower in participants than in the population. However this comparison does not take into account the fact that all SAPALDIA participants had to be local residents for at least 3 years. The respective data was available only for Basle, and here it could be clearly seen that the proportion of foreigners was lower in the participants $(18.2 \%, \mathrm{n}=1487)$ than in the 3 year residents of the same age group $(21.5 \%, \mathrm{n}=95627)$, but the difference was smaller than compared to the whole population without restriction on the length of residency $(24.4 \%, \mathrm{n}=$ 115075).

\section{Smoking}

Out of the 4734 male participants who had answered the respective questions, $35.8 \%$ were people who had never smoked regularly in their life (never-smokers), $25.7 \%$ were people who had stopped smoking (ex-smokers) and $38.5 \%$ were regular smokers. For the 4902 female participants who had answered the questions, the respective proportions were $51.7 \%$ neversmokers, $19.5 \%$ ex-smokers and $28.8 \%$ current smokers.

For $74.0 \%$ of the non-participants information was available from the telephone interview, whether they had ever smoked for at least one year. The proportion of neversmokers was $58.2 \%$ in female $(n=2271)$ and $41.3 \%$ in male nonparticipants $(n=1963)$. For $31.1 \%$ of the non-participants information was available from the mailed short questionnaire, where the question had been asked "are you a smoker, ex-smoker or non-smoker?" The respective proportions were $28.7 \%, 13.5 \%$ and $57.8 \%$ in female non-participants $(\mathrm{n}=1132)$ and $36.8 \%, 17.5 \%$ and $45.7 \%$ in male non-participants $(\mathrm{n}=914)$. Comparing the proportion of nonsmokers in these groups to the never-smokers as derived from the telephone interview, the proportion was slightly smaller in the female non-participants with a mailed questionnaire $(p=0.81$ derived from $\chi^{2}$ test) and significantly higher in the male non-participants with a mailed questionnaire $(\mathrm{p}=0.02)$.

Comparing the smoking status of participants to the one of nonparticipants with a telephone interview, the proportion of neversmokers was significantly lower in both female $(51.7 \%$ versus $58.2 \%$ in non-participants, $\mathrm{p}<0.001)$ and male participants $(35.8 \%$ versus $41.3 \%, \mathrm{p}<0.001)$.

Comparing the participants to the non-participants with a mailed short questionnaire, the propor- 
tions of current smokers were practically identical for both genders $(28.8 \%$ versus $28.7 \%$ in females, $38.5 \%$ versus $36.8 \%$ in males). The proportion of ex-smokers was significantly higher in both female $(19.5 \%$ versus $13.5 \%$ in non-participants, $\mathrm{p}<0.001)$ and male $(25.7 \%$ versus $17.5 \%, \mathrm{p}<0.001)$ participants, therefore reducing the proportion of never-smokers in participants $(51.7 \%$ versus $57.8 \%$ in female non-participants, $35.8 \%$ versus $45.7 \%$ in males).

However there are indications of a possibly important misclassification error due to a misunderstanding of the question in the mailed short questionnaire "are you a smoker, ex-smoker or non-smoker?" A number of participants of the SAPALDIA study had also received the mailed short questionnaire and answered the question on smoking $(n=195)$ and so it was possible to validate these answers against the stepwise deduction of smoking status in the computerised interview ("have you ever smoked for as long as a year, do you smoke now", etc.): 11 out of 35 exsmokers (as defined by the interview) had described themselves as non-smokers instead of exsmokers in the short questionnaire.

\section{Prevalence of symptoms}

Questions on asthma ("have you had an attack of asthma within the last 12 months?"), wheezing apart from cold ("have you had wheezing or whistling in your chest at any time in the last 12 months when you did not have a cold?"), phlegm ("do you usually bring up phlegm on most days for as much as 3 months each year?") and allergic rhinitis ("do you have any nasal allergies including hay fever?") were asked in both the SAPALDIA interview questionnaire and in the mailed short questionnaire of the European Community Respiratory Health Survey sent to all non-participants. As the short questionnaire was filled in by 2244 of the 6616 non-participants, it was possible to compare symptom prevalences in participants and non-participants. Table 9 shows the results of this comparison of the raw data. Compared to participants, non-participants were less likely to report asthma, wheezing apart from cold and allergic rhinitis, but more likely to report phlegm.

To account for the known influences of age, sex and smoking status on symptom prevalence, logistic regression models were calculated controlling for these variables plus area, but the strength of the associations was essentially unchanged (Table 10).

Using the logistic regression model described above, the strength and direction of the association was compared between centres by including centre-participation interaction terms. The effects of participation did not vary significantly at the $5 \%$ level for asthma, wheezing nor phlegm. For allergic rhinitis however, the association with participation varied significantly across centres, resulting in odds ratios

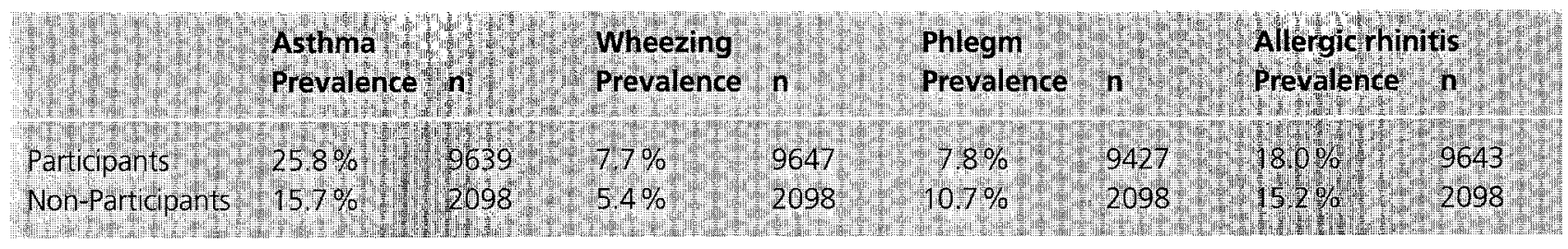

Table 9. Prevalence of symptoms in participants and non-participants of the SAPALDIA cross-sectional study. Information on symptoms was available through the mailed short questionnaire of the European Community Respiratory Health Survey for $31.8 \%$ of the 6616 non-participants. Raw data.

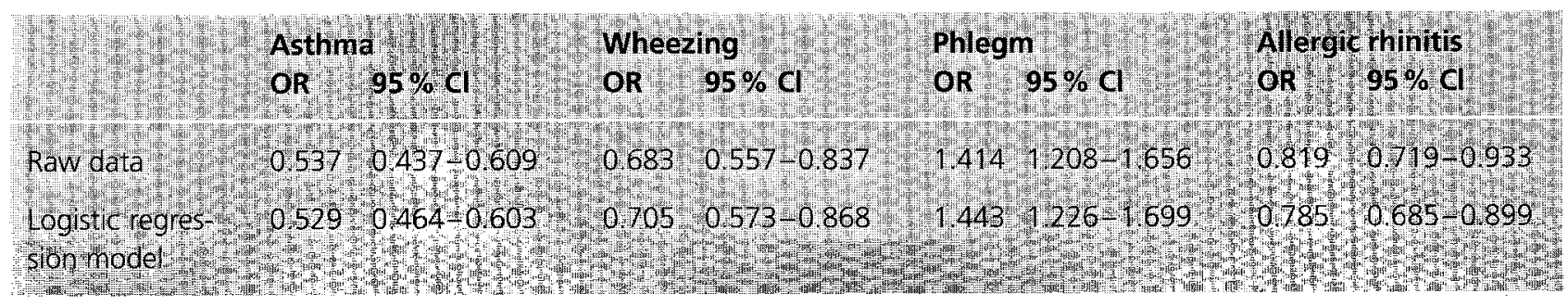

Table 10. Odds ratios for reporting symptoms in non-participants compared to participants. Logistic regression model controlling for age, sex, smoking status and area. For asthma, wheezing and phlegm there was no significant difference in the strength and direction of the association across centres, for allergic rhinitis the associations varied significantly with odds ratios ranging from 0.52 to 1.29 


\begin{tabular}{|c|c|c|c|c|}
\hline & Switzerlal & lents $04.12 .90,18-60$ years & SAPALD & ticipants \\
\hline & Female & Male & Female & Male \\
\hline Urban/suburban population & 1473911 & 1508349 & 2600 & 2499 \\
\hline & $71.3 \%$ & $69.8 \%$ & $53.0 \%$ & $52.7 \%$ \\
\hline Rural population & 593918 & 651693 & 2308 & 2244 \\
\hline$\therefore$ & $28.7 \%$ & $30.2 \%$ & $47.0 \%$ & $47.3 \%$ \\
\hline Total & 2067829 & 2160042 & 4908 & 4743 \\
\hline & $100 \%$ & $100 \%$ & $100 \%$ & $100 \%$ \\
\hline
\end{tabular}

Table 11. Urban/suburban and rural population in Switzerland (18-60 years of age; Swiss Federal Office of Statistics, personal communication) and in the participants of the SAPALDIA cross-sectional study. Differences between genders are small, for both genders the proportion of the urban/suburban population is substantially smaller in the SAPALDIA participants.

ranging from 0.52 in Aarau to 1.29 in Geneva.

Because some of the centres were known for their clean air or their respiratory medicine institutions, it was possible that some people might have moved there seeking help for their respiratory problems. Therefore from March 1991 on all participants were asked whether they had been living in the area since they were born, and if not, what were their reasons for moving there. In all centres less than $1 \%$ of the participants had moved to the area for health reasons with the exception of Davos, where this was the case for $34(5.7 \%)$ of the 596 participants who answered the question. $21(3.5 \%)$ of them reported having moved there because of asthma, $7(1.2 \%)$ because of other respiratory diseases. The group of people having moved to Davos because of health problems represented 24 of the 54 participants reporting doctor's diagnosed asthma $(n=597)$ and 14 of the 18 participants reporting current asthma symptoms $(\mathrm{n}=594)$.

\section{Degree of urbanisation}

The centres of the SAPALDIA study were chosen to represent the variety of environmental condi- tions found in Switzerland and not the varying patterns of urbanisation throughout the country. By the end of 1990, more than two thirds of the residents of Switzerland were living in urban or suburban areas $^{24}$, while only the study centres Geneva, Basle, Lugano and Aarau fit this description. Table 11 shows the exact numbers for both the Switzerland residents of 18 60 years and the participants of the SAPALDIA cross-sectional study.

\section{Discussion}

To achieve the aims of the SAPALDIA study which are the assessment of the prevalence of bronchial asthma, chronic bronchitis and allergic conditions in the adult population of Switzerland and the identification and the determination of the respective importance of potentially influencing factors, two issues are of crucial importance: The standardisation of assessment techniques and the avoidance of any relevant selection bias.

\section{Standardisation of methods}

To achieve a satisfying standardisation of instruments, several steps were taken. All methods of the health assessment were developed along with the questionnaire of the European Community Respiratory Health Survey and evaluated and validated in detail before the beginning of investigations. For the computerised SAPALDIA questionnaire the preferential use of questions established in other questionnaires like the one of the MONICA study and a sophisticated system of translation and crosstranslation minimised linguistic differences in the German, French and Italian version. All study centres were run under the resposibility of a qualified respiratory physician with vast experience in lung function testing and allergy skin testing. For endexpiratory CO-measurements a pilot study was undertaken before the beginning of the SAPALDIA study that confirmed the reliability of the method.

A steering committee composed of members of the SAPALDIA team representing all disciplines involved met monthly to follow the course of the study and to take care of general coordination, participation and quality control.

The fieldworkers, including a junior physician in each centre, were extensively instructed and trained and were given detailed written instructions on all health assess- 
ment techniques. Before the first SAPALDIA participant ever entered a study centre, all techniques were practised on volunteers.

After the beginning of investigations the local teams were in close contact with both the local responsible respiratory physician and the central epidemiology unit of the study at the Institute of Social and Preventive Medicine in Basle. Apart from individual contacts through telephone and personal visits regular meetings were held, uniting the fieldworkers of the different centres to discuss problems and give new instructions. Regular calibration of the instruments was performed for pulmonary function testing, methacholine challenge testing and endexpiratory $\mathrm{CO}$ measurements. A number of quality control measurements were introduced particularly on pulmonary function testing ${ }^{17}$ and allergy skin testing to maintain a high level of quality.

After the data collection period all spirometry outputs were visually screened by a junior physician with experience in lung function testing and a qualified respiratory physician. Their judgement and critical remarks of the spirometry technicians were used as additional quality standards to the established ATS criteria. As the decision about the inclusion or exclusion of spirometry curves and values was based on quality criteria alone and not on the size of the outcome measurements, no selection bias has to be expected.

To rule out any possible effect of the changing of all nebulisers in spring 1991, the bronchial reactivity data were checked for any differences before and after the exchange or any time trend, but no such effects could be detected.

Specific methods of standardisation were applied for the environmental data assessment and deviations in accuracy could be quantified. More information on this subject can be found in a separate publication ${ }^{21}$.

\section{Selection of participants}

To obtain a high participation in the random samples drawn from the local registries of inhabitants and to avoid any important selection bias, different strategies were chosen to approach the participants. The study was presented in the national media and local publicity campaigns were organised by the local respiratory physicians when the sample was first contacted. Letters of invitation were written including information on the aims and the design of the study and people were invited to send back prepared postcards to confirm their participation. If no postcard was returned, efforts were made to contact the individuals through repeated telephone calls, and if necessary personal visits were made to the homes of individuals. So only 279 people, representing $1.7 \%$ of the total sample of 16267 , could not be reached.

9651 individuals agreed to come to the study centres for the examination of about $1 \frac{1}{2}$ hours, representing a participation rate of $59.3 \%$ (Table 6). The relatively high differences in participation between the study centres might be due to the different size, social structure and cultural background of the areas as well as to the differing promotional strategies applied locally. Looking at the completeness of the different tests (Table 7), all participants by definition had completed the computerised interview and more than $97 \%$ had completed spirometry, endexpiratory $\mathrm{CO}$ testing and allergy skin testing. Serological testing requiring the taking of a blood sample and bronchial challenge testing requiring the inhalation of a potentially scaring chemical agent were less complete with participation varying considerably across centres. $75.3 \%$ of all participants had a complete set of tests (Table 8), with a slightly higher rate in male $(79.4 \%)$ than female participants $(71.4 \%)$. As participants were informed about all tests in advance and were free not to take part in any of them, these differences between centres and also between genders might be the expression of different ways of approaching and reassuring participants in addition to the reasons mentioned above.

With a non-participation rate of $40.7 \%$ there is a potential for selection bias. To quantify this potential additional information on non-participants was gained by telephone interviews during the first contact and by the mailed short questionnaire of the European Respiratory Health Survey. Comparing nonparticipants to participants, an overrepresentation of the intermediate age group (30-44 years) could be seen in participants. The practical implications of this moderate distortion of the age structure are limited but point out the importance of presenting age standardised prevalences and of controlling for age in modelling. The gender ratio was practically identical in participants, in non-participants, and also in the general population of the study centres in the respective age group (18-60 years).

For nationality, no information was available on non-participants. When comparing participants to the population of local residents for at least three years (data available only for Basle), or particularly to the local population of $18-60$ years without any restriction on the time of residency, a clear underrepresentation of non-Swiss nationals could be seen. This might be due to the known limitations in efficiently involving foreign populations in promotional activities targeted at the general population rather than at specific subgroups.

Data on smoking status were available for both participants and a good part of non-participants. As could be expected, the proportion of current smokers and also former smokers or ex-smokers was substantially lower in females. Com- 
bining the information from the different sources, in participants of both genders the proportion of current smokers was about the same as in non-participants. Exsmokers seemed to be moderately overrepresented, therefore reducing the proportion of neversmokers.

Non-response bias is known to be an important factor in epidemiological studies ${ }^{25}$. A detailed investigation of the question in the SAPALDIA centre of Payerne showed a tendency of higher prevalences of respiratory symptoms in participants compared to nonparticipants, though significant differences could be seen only for wheezing within the last 12 months (12.5\% in participants versus $5.6 \%$ in non-participants) ${ }^{26}$. The results in Tables 13 and 14 show the expected overrepresentation of individuals reporting asthma, wheezing, and allergic rhinitis in the participants of the study. These differences are smaller than the one seen for wheezing in the study in Payerne and could partly be due to oral explanations given during the SAPALDIA interview. The inverse relationship for phlegm is surprising and could partly be explained by a greater reluctance of reporting a symptom perceived as disgusting to an interviewer in the computerised questionnaire as opposed to simply crossing an answer in the short questionnaire. This explanation is supported by observations made in the 185 participants who answered the respective questions in both the EC short questionnaire and the computerised SAPALDIA questionnaire: 9 of them reported phlegm in both questionnaires, 6 in the computerised questionnaire only and 19 in the short questionnaire exclusively.

As comparing prevalences across centres is a crucial issue of SAPALDIA, it is very reassuring to see that the observed selection bias is uniform across centres for asthma, wheezing and phlegm. For allergic rhinitis however, the association varies widely. The German speaking centres (Aarau, Basle, Davos and Wald) seem to form one group with odds ratios ranging from 0.52 to 0.62 and the French speaking (Geneva, Payerne and Montana; OR 0.83-1.29) and Italian speaking (Lugano, OR $0.96)$ centres a second group. The 192 participants who answered the respective questions in both the EC short questionnaire and the computerised SAPALDIA questionnaire show a slightly better though not significantly different correspondence between the two questionnaires in the German speaking than in the non-German speaking centres and therefore support the idea of an intercultural difference.

Slightly more than half of the SAPALDIA participants lived in a urban or suburban surrounding compared to about $70 \%$ of the residents of Switzerland of $18-60$ years (Table 11). This illustrates that the SAPALDIA centres were chosen to represent the different environmental conditions found in Switzerland and not the population of Switzerland as a whole.

The restriction of the study base to the age group of 18 to 60 years had the objective to study effects in the working age segment of the population. The effects in children were addressed in the separate Swiss Study on Childhood Allergy and Respiratory Symptoms with Respect to Air Pollution and Climate SCARPOL ${ }^{27}$. The exclusion of individuals who had been living in the area for less than three years was an attempt to improve long-term exposure classification.

The SAPALDIA participants represent the adult permanent residents of the study centres. The good representation of males and females and of both smokers and non-smokers give the possibility of coming to conclusions about these groups. The moderate distortion of the age structure will be accounted for by age-standardisation or controlling for age. The moderate overrepresentation of ex-smokers is irrelevant because analyses will either use stratification by or controlling for smoking status. The differences in reporting symptoms between participants and nonparticipants can be partly explained by different questionnaire techniques or intercultural differences. The relative importance of these effects should be determined by further investigation. The uniformity of the selection effects between centres for respiratory symptoms indicates an acceptable comparability. 


\section{Zusammenfassung}

SAPALDIA: Methodik und Beteiligung im Querschnittsteil der Schweizer Studie Luftschadstoffe und Lungenkrankheiten bei Erwachsenen

SAPALDIA, die Schweizer Studie Luftschadstoffe und Lungenkrankheiten bei Erwachsenen, konzentriert sich auf die langfristigen gesundheitlichen Auswirkungen von tiefen bis mässig erhöhten Konzentrationen von Luftschadstoffen, wie sie typischerweise in verschiedenen Gebieten der Schweiz vorkommen. Ziel der 1991 durchgeführten Querschnittstudie SAPALDIA war die Bestimmung der Prävalenz von Asthma bronchiale, chronischer Bronchitis und allergischen Beschwerden in der erwachsenen Bevolkerung der Schweiz sowie die ldentifizierung und Quantifizierung möglicher Einflussfaktoren. Dazu gehören sowohl individuelle (Rauchverhalten, Allergiestatus, familiäre Anamnese, Belastung am Arbeitsplatz) als auch umweltbedingte Faktoren (Raumluftbelastung, Aussenluftuerschmutzung, inhalative Allergene, Klima). Ein weiteres Ziel der Studie war die Identifizierung von Persohen, bei denen das Auftreten von Symptomen während einer zweijährigen Beobachtungsperiode zu erwarteh war und die deshalb in die SAPALDIA-Langsschnittstudie aufgenommen werden konnten. Der vorliegende Artikel stellt die methodische Basisdokumentation fur die SAPALDIA-Querschnittstudie dar. Die Untersuchungsinstrumente und die verwendeten Standardisierungsmethoden werden vorgesteflt und diskutiert. Eine volle Untersuchung umfasste folgende Bestandteile: ein Computer-gestutztes interview mit einem standardisierten Fragebogen, eine Blutentnahme für serologische Untersuchungen, Allergie-Haut-Tests, eine Bestimmung des endexpiratorischen Co in der Ausatmungsluft, eine Messung der Körpergrösse, eine Lungenfunktionsprufung und anschliessend je nach deren Resultat entweder einen inhalativen Provokationstest mit Methacolin oder einen Bronchodilatationstest. Mit 9651 Teilnehmerinnen und Teilnehmern wurde eine Beteiligung von $59,3 \%$ erzielt. Die Betelligung bei den verschiedenen Tests, die Merkmale der Teilnehmer sowie diejenigen der Nicht-Teilnehmerinnen und Nicht-Teilnehmer, ermittelt anhand von Informationen aus Telephonbefragungen und kurzen schriftlichen Fragebogen, werden beschrieben und diskutiert

\section{References}

1 Thom ThJ. International comparisons in COPD mortality. Am Rev Respir Dis 1989; 140:S27-S34.

2 Zellweger JP, Leuenberger Ph, Mocostabella $P$. Prévalence de l'hyperréactivité bronchique dans une population d'adultes valides. Schweiz med Wschr 1985; 115: 1368-1370.

3 Wüthrich B. Epidemiology of the allergic diseases: are they really on the increase? Int Arch Allergy Appl Immunol 1989; 90:3-10.
4 Burney $P$. Why study the epidemiology of asthma? Thorax 1988; 43:425-428.

5 Cullinan $P$, Newman Taylor AJ. Asthma in children: environmental factors. Brit Med J 1994; 308: $1585-$ 1586.

6 Pope III CA, Dockery DW. Acute health effects of PM10 pollution on symptomatic and asymptomatic children. Am Rev Respir Dis 1992; 45:1123-1128.

7 Romieu I, Meneses F, Sienra-Monge $J J L$ et al. Effects of urban air pollutants on emergency visits for child- hood asthma in Mexico City. Am J Epidemiol 1995; $141: 546-553$.

8 Keller R, Baltzer Ph, Keller-Wossidlo H, Gamp R, Ragaz A. Schaub Th. Akute Auswirkungen der natürlichen atmosphärischen Ozonbelastung auf die Lungenfunktion von klinisch gesunden Rauchern und Nichtrauchern. Schweiz med Wschr 1990; 120:1724-1730.

9 Braun-Fahrländer Ch, Künzli $N$, Domenighetti $G$, Carell CF, Ackermann-Liebrich $U$. Acute effects of ambient ozone on respiratory function of Swiss schoolchildren after a 10-minute heavy exercise. Ped Pulm 1994; 17:169-177.

10 Schüler G, Stransky M, Epstein FH, Schär $M$. Respiratorische Symptome, chronische Bronchitis. Befragung in zwei Zürcher Landgemeinden (1974-1975). Schweiz Rundschau Med (PRAXIS) 1980; 69:950-957.

11 Braun-Fahrländer Ch, AckermannLiebrich U, Gnehm HP, Ruthishauser $M$, Wanner $H U$. Air pollution and respiratory symptoms in preschool children. Am Rev Respir Dis 1992; 145:42-47.

12 Gschwend S, D'Apuzzo V, Schöni $M$, Krämer $R$. Einfluss der Luftschadstoffbelastung auf gesunde und lungenkranke Kinder im Südtessin. Schweiz med Wschr 1989; 119:1868-1874.

13 Burney PGJ, Luczynska C, Chinn S, Jarvis $D$ et al. The European Community Respiratory Health Survey. Eur Respir J 1994; 7:954-960.

14 Leuenberger $P$, Schwartz J, Ackermann-Liebrich $U$ et al. Passive smoking exposure in adults and chronic respiratory symptoms (SAPALDIA study). Am J Respir Crit Care Med 1994; 150:1222-1228.

15 Bundesamt für Statistik. Statistisches Jahrbuch der Schweiz. Bern, Verlag Neue Zürcher Zeitung 1993: 52 .

16 ATS (American Thoracic Society). Standardisation of spirometry 1987 update. Am Rev Resp Dis 1987; 136:1285-1298.

17 Künzli N, Ackermann-Liebrich $U$, Keller R, Perruchoud A, Schindler 


\section{Résumé}

\section{SAPALDIA: Méthodes et participation dans l'étude transversale du projet suisse sur la pollution atmosphérique et les maladies respiratoires chez l'adulte}

Le projet suisse SAPALDIA sur la pollution atmosphérique et les maladies respiratoires chez ladulte étudie les effets sur la santé des polluants de T'air à des concentrations moyennement élevées telles qu'on les mesure typiquement dans les différentes régions de Suisse. L'étude transversale réalisée en 1991 visait à déterminer la prévalence de l'asthme bronchique, de la bronchite chronique et des allergies respiratoires dans la population adulte en Suisse ainsi qu'à identifier et à quantifier les facteurs d'influence, soit de nature individuelle (tabagisme, status allergique, anamnèse familiale, occupation) soit environnementale (pollution de l'atmosphère intérieure ov extérieure, allergènes inhalés, climat). Un autre but de l'étude transversale etait d'identifier des personnes présentant un risque significatif de développer des symptômes au cours d'une étude de surveillance longitudinale trealisée en 1992 et 1993). Cet article représente la documentation méthodologique de l'étude transversale SAPALDIA. Les instruments de létude et les méthodes de standardisation sont présentés et discutés. L'examen médical consistait en un interview assisté par ordinateur en utilisant un questionnaire standardisé, en un prélèvement de sang pour des tests sérologiques, en tests cutanés d'allergie, en mesure du CO en fin d'expiration et en un examen de fonctions pulmonaires suivi d'un test de provocation à la methacholine ou d'un test de bronchodilatation selon le résultat de la spirometrie. La participation et les caractéristiques des 9657 participants - représentant $59.3 \%$ de l'échantillon - sont présentées et discutées. Au moyen d'interviews téléphoniques et de courts questionnaires écrits, les caracterristiques des non-participants ont pu être comparées à celles des participants.
Ch and SAPALDIA-Team. Variability of FVC and FEV1 due to technician, team, device, and subject in an eight centre study. Three quality control studies in SAPALDIA. Eur Resp J 1995; 8:371-376.

18 Quanjer PhH. Standardized lung function testing. Bull Eur Physiopath Resp 1983; 19 (suppl 5):1-95.

19 Wüthrich B, Schindler Ch, Leuenberger $P$, Ackermann-Liebrich $U$ and the SAPALDIA-Team. Prevalence of Atopy and Pollinosis in the Adult Population of Switzerland (SAPALDIA study). Int Arch Allergy Immunol 1995; 106:149156.

20 Merrett J, Merrett TG. Phadiatopa novel $\operatorname{IgE}$ antibody screening test. Clin. Allergy 1987; 17:409-416.
21 Monn Ch, Defila C, Alean-Kirkpatrick $P$. et al. Air pollution in urban, rural and alpine air in Switzerland (SAPALDIA-study). Staub, Reinhaltung der Luft, in print.

22 Monn Ch, Braendli O, Schaeppi $G$ et al. PM10 and TSP in urban, rural and alpine regions in Switzerland (SAPALDIA-study). Atmospheric Environment, in print.

23 Alean-Kirkpatrick P, Hertz J. DEMONS in Switzerland: practical considerations and first year's results from a monitoring network for $\mathrm{HNO}_{3}$ and $\mathrm{NH}_{3}$. EMEP/CCCreport 1/1993, reference O-7727: EMEP-workshop on measurements of nitrogen containing compounds.
24 Bundesamt für Statistik. Statistisches Jahrbuch der Schweiz. Bern, Verlag Neue Zürcher Zeitung 1995: 23-35.

25 De Marco $R$, Verlato $G$, Zanolin $E$, Bugiani $M$, Drane JW. Nonresponse bias in EC Respiratory Health Survey in Italy. Eur Resp J 1994; 7:2139-2145.

26 Luthi J-Ch. Etude du biais dû aux non-répondants dans une étude épidemiologique (SAPALDIA) [Thèse]. Lausanne: Faculté de Médecine de l'Université de Lausanne, 1993.

27 Braun-Fahrländer Ch, Vuille JC, Sennhäuser $F H$ et al. Respiratory health and long-term exposure to air pollutants in Swiss school children. Am J Respir Crit Care Med, in press.

\section{SAPALDIA Team}

Study director: Ph. Leuenberger (p) Programme director: U. AckermannLicbrich (e), P. Alean (am), K. Blaser (a), G. Bolognini (p), J.P. Bongard (p), O. Brändli (p), P. Braun (p), C. Bron (I), M. Brutsche (l), C. Defila (m), G. Domenighetti (p), S. Elsasser (1), L. Grize (s), P. Guldimann (1), C. Hollenstein (1), P. Hufschmid (1), W. Karrer (p), K. Keller-Wossidlo (o), R. Keller (p), N. Künzli (e), J.C. Luthy (1), B. W. Martin (e), T. Medici (p), Ch. Monn (am), A.G. Peeters (pa), A.P. Perruchoud (p), A. Radaelli (1), Ch. Schindler (s), J. Schwartz (s), G. Solari (p), M. Schöni (p), J.M. Tschopp (p), B. Villiger (p), B. Wüthrich (a), J.J. Zellweger (p), E. Zemp (e).

(a): allergology, (am): air pollution monitoring, (e): epidemiology, (l): local assistant (MD), (M): meterology, (o): occupational medicine, $(\mathrm{p})$ : pneumology, (pa): palynology, (s): statistics.

\section{Participating institutions}

Divisions of Respiratory Medicine, University Hospitals of Lausanne, Basle and Zurich; Institute of Social and Preventive Medicine, University of 
Basle; Allergy Unit, Department of Dermatology, University Hospital Zurich; Swiss Institute of Allergy and Asthma Research, Davos; Klinik Barmelweid, Aarau; Kinderklinik Pro Juventute, Davos; Zürcher Höhenklinik Clavadel, Davos; ThurgauischSchaffhausische Höhenklinik, Davos; Ospedale la Carita, Locarno; Luzerner Höhenklinik, Montana; Centre Valaisan de Pneumologie, Montana; Zürcher Höhenklinik, Wald; private practices in Fribourg, Geneva, Lugano and Mendrisio; Institute of Hygiene and Applied Physiology at the Swiss Federal Institute of Technology Zurich.

\section{Acknowledgements}

The authors wish to thank the institutions in the environmental measure- ments: Luftelektrische Station Aarau; Amt für Umweltschutz Graubünden; Landschaft Davos; Service Cantonal d'Ecotoxicologie Geneva, Lufthygieneamt beider Basel, Sezione Energia e Protezione Aria (Dipartimento del Ambiente Ticino); Service de la Protection de l'Environnement du Canton Valais; Kantonales Amt für Technische Anlagen und Lufthygiene Zürich; EMPA Dübendorf (responsible for the NABEL measurements). Further technical support was granted from: Centre Valaisan de Pneumologie Montana; Institut Suisse de la Méteorologie Payerne; Forschungsstelle für Umweltbeobachtung $\mathrm{Egg} / \mathrm{ZH}$; Institut für Anorganische Chemie, University of Berne; Anorganisches Institut, University of Zurich; Spital Wald. The authors' special thanks go to the team fieldworkers in Aarau, Basle, Davos,
Geneva, Lugano, Montana, Payerne and Wald. They also wish to thank the technicians of the Allergy Laboratory at the Department of Dermatology of the University Hospital Zurich, the Hôpital de Zone, Payerne and the collaborators of Kabi-Pharmacia, Dübendorf, and the authorities of the participating cantons of Aargau, Basle, Geneva, Vaud, Valais, Zurich, Ticino and Grisons for their logistic and financial support.

\section{Address for correspondence}

Dr. med. Brian W. Martin Institute of Sports Sciences Swiss Sports School Magglingen CH-2532 Magglingen 